\title{
The sustainability-peace nexus: why is it important?
}

\author{
Ayyoob Sharifi' ${ }^{1,2} \cdot$ Dahlia Simangan ${ }^{1,2} \cdot$ Shinji Kaneko ${ }^{1,2} \cdot$ Hassan Virji,
}

Received: 19 May 2021 / Accepted: 8 June 2021 / Published online: 12 June 2021

(c) The Author(s), under exclusive licence to Springer Japan KK, part of Springer Nature 2021

\begin{abstract}
Sustainability and peace have long been recognized within academic and policy circles as intrinsically interrelated. Although there are some studies that examine impacts of sustainability on peace and vice versa, a specific focus on the sustainability-peace nexus remains marginal in academic and policy discourses, and pathways where sustainability and peace interact remain ambiguous. As a result, global initiatives on peace and sustainability remain fragmented. It is, therefore, crucial to identify the different components that mutually reinforce the desirable outcomes from sustainability and peace initiatives. This special feature of Sustainability Science aims to contribute to a better understanding of these components by highlighting the emerging discourses on the peace-sustainability nexus and the issues surrounding it. It includes articles that provide insights to better address issues at the nexus of peace and sustainability. Key takeaways for scientists and policy makers are that systemic approaches are needed to capture the multiple dynamic interactions between peace and sustainability; addressing issues at the intersection of peace and sustainability requires interactions between a wide range of stakeholders within and across various local, regional, national, and global scales; and international scientific collaboration is essential for comprehensive understanding of the interactions between peace and sustainability. We hope that this special feature will contribute to a better understanding of the complexities of the peace-sustainability nexus and provide insights into developing more effective solutions and strategies for making progress towards creating more peaceful and sustainable communities in the future.
\end{abstract}

Keywords Sustainability $\cdot$ Peace $\cdot$ Sustainability-peace nexus $\cdot$ Climate change $\cdot$ Environmental security

Sustainability and peace have long been recognized within academic and policy circles as intrinsically interrelated (Sharifi et al. 2021). In the 1990s, global warming and other forms of environmental degradation prompted increased scholarly attention on the relationship between conflict and the environment. Specifically, previous studies had shown the significant role of natural resources in shaping the conditions that either enable peace or incite conflict. On the one hand, there is ample evidence that environmental

Handled by Osamu Saito, Institute for Global Environmental Strategies, Japan.

Ayyoob Sharifi

sharifi@hiroshima-u.ac.jp

1 Graduate School of Humanities and Social Sciences, Hiroshima University, Higashi-Hiroshima, Japan

2 Network for Education and Research on Peace and Sustainability, Hiroshima University, Higashi-Hiroshima, Japan degradation, especially when it leads to resource scarcity, can incite conflict, either by exacerbating existing sources of conflict or renewing old ones (e.g., Buhaug et al. 2008; Hauge and Ellingsen 1998). On the other hand, challenges related to access and distribution of natural resources can be an opportunity for establishing mechanisms of cooperation (e.g., Brock 1991; Conca and Dabelko 2002). Although there has been a proliferation of studies that examine the impact of conflict on the environment and vice versa, a specific focus on the sustainability-peace nexus remains marginal in academic and policy discourses.

Sustainability and peace scholars are instrumental in calling attention to global, national, and local issues and opportunities that lie at the intersections of sustainability and peace. The field of environmental peacebuilding, for instance, shifts away from conflict-centered and deterministic environment-conflict discourses and towards environmental conflict resolution and positive-sum interactions (Conca and Dabelko 2002). Although research on environmental peacebuilding helps illuminate the confounding variables 
between the environment and peace, in some instances, however, it overlooks the root causes of environmental issues, thereby contributing to social discrimination and conflict deterioration, among other unintended consequences (Ide 2020). Meanwhile, efforts to address the conceptual shortcomings of sustainable development and sustainability are noteworthy. For instance, the adoption of the UN Agenda 2030 (particularly Goal 16 on peace, justice and strong institutions) punctuates the link between sustainability and peace. Despite these advancements, the relationship between environmental sustainability and peace remains under-examined.

Examining the relationship between sustainability and peace demands a shared understanding of what these two concepts mean as they can be interpreted in different and even competing ways. Peace has no canonical definition, but there have been a plethora of attempts to capture its meaning. Peace and conflict researchers often cite the work of Johan Galtung on peace and violence as the starting point. He conceptualized peace as not just the absence of war but also of structural and more invisible forms of violence (Galtung 1969). Peace, therefore, is holistic, consisting of both the absence of physical harm and direct conflict (i.e., negative peace) and the presence of conditions leading to peaceful, inclusive, and just societies (i.e., positive peace). Peace considerations at the international level are also associated with research and policy on development, justice, and environmental sustainability (Richmond 2008). Existing measurements or approaches to studying peace imply this holistic conceptualization-from the quality of peace (IEP 2019), the voices that define peace (Mac Ginty and Firchow 2016), the degree of peace and its variations among societies (Davenport et al. 2018), and specific characteristics of peace (Jarstad et al. 2019). However, previous studies on peace and its relationship with sustainability challenges, such as climate change, focused mainly on direct forms of violence or armed conflicts (Sharifi et al. 2020). Hence, sustainability and peacebuilding approaches would benefit from integrating more systematically a holistic conceptualization of peace.

Similarly, sustainability has no canonical definition, but discussions around it cannot be decoupled from economic development, social equity, environmental protection, security, happiness, and the good life, among other concepts. One commonly cited definition of sustainable development is from the 1987 Our Common Future Report of the World Commission on Environment and Development (WCED), also known as the Brundtland Report. It states that "sustainable development is development that meets the needs of the present without compromising the ability of future generations to meet their own needs" (UN WCED 1987, para. 27). The Sustainable Development Goals (the 2030 Agenda) took a broader and more holistic conceptualization by aiming to achieve "sustainable development in its three dimensions-economic, social, and environmental dimensions-in a balanced and integrated manner" (UN 2015, p. 3). Sustainable development and peace are the pillars of the 2030 Agenda, which details how to achieve both sustainability and peace but lacks explicit definitions of either. What is clear from the current discussions on sustainable development, nonetheless, is that the intersection of sustainability and peace cuts across environmental, social, political, and economic dimensions.

The concepts of sustainability and peace are multi-dimensional and constantly evolving, and the pathways of their relationship are complex and dynamic. More recent studies have started considering the myriad factors and mechanisms that influence this relationship, particularly that of between climate and conflict (IPCC 2014; Koubi 2019). They shed light on the mediating role of political institutions, economic conditions, and social practices, especially in understanding the implications of climate for security (e.g., Hendrix and Haggard 2015; Koubi et al. 2012; Uexkull et al. 2016). However, the pathways where sustainability and peace interact remain ambiguous. As such, empirical evidence that provides a better understanding of the outcomes of these pathways appears limited due to the various social, political, and economic factors and contexts that are constantly shaping and reshaping the conditions for sustainable and peaceful societies. As a result, global initiatives on peace and sustainability remain fragmented. It is, therefore, crucial to identify the different components that mutually reinforce the desirable outcomes from sustainability and peace initiatives.

This special feature of Sustainability Science aims to contribute to a better understanding of these components by highlighting the emerging discourses on the peace-sustainability nexus and the issues surrounding it. "Probing the complex and dynamic interactions between the humannatural earth system and providing better knowledge on how global changes affect our ability to attain sustainable development and peaceful coexistence" is of paramount importance (Virji et al. 2019, p. 1468). For this reason, this special feature aims to engage academics, policymakers, and private stakeholders from sustainability science with scholars and practitioners of peace and conflict studies. It serves as a platform for integrating relevant disciplines and facilitating a conversation and collaboration towards the common goal of achieving sustainability and peace. In this time of rapid and complex global transformations, as manifested in climate change and the COVID-19 pandemic, collaborative and transdisciplinary research is an endeavor worth undertaking amidst global challenges to sustainability and peace. This special feature is a response to such challenges.

The papers included in this special feature contribute to unpacking some of the complex interactions between peace and sustainability and analyzing the nexus dynamics 
from different perspectives. They also provide examples of the multiple interactions between peace and sustainability. The study by Simangan et al. (2021) reports on activities conducted during the Hiroshima Dialogue Forum on the Sustainability-Peace Nexus in the Context of Global Change https://www.hiroshima-u.ac.jp/en/news/53192 that was organized by Hiroshima University's Network for Education and Research on Peace and Sustainability (NERPS) in 2019 to investigate the sustainability-peace nexus in the context of global change. Indeed, the idea to publish a special feature on the nexus emerged from this transdisciplinary workshop. Through the lens of various relevant environmental, socio-political, and economic and technological factors, Simangan et al. (2021) discuss how, as a process or a condition, peace can contribute to or detract from sustainability and vice versa. Accordingly, they introduce a heuristic co-designed framework for examining the nexus that can be used by interested scientists and policy makers in their efforts to understand the nexus complexities. The framework underscores the need for systemic approaches. An example of such approaches is provided by Amadei (2021). His model shows how the peace-sustainability nexus is influenced by interactions between multiple systems and sub-systems across different scales. Given such complex interactions, Amadei (2021) argues that both peace and sustainability (and their nexus) are dynamic phenomena that should be addressed using systemic approaches and dynamic models that can capture the complex, pluralistic, and multidimensional nature of the nexus. The need for taking holistic and systemic approaches to address the nexus has also been highlighted by Sharifi et al. (2020) who have focused on the nexus between climate and conflict. Their review study demonstrates that there is a rich body of literature on the nexus, particularly with regard to the interactions between climate change and conflict. Through an overview analysis of three decades of research, they show that the recognition of the nexus has progressively grown, especially since the publication of the fourth assessment report of the Intergovernmental Panel on Climate Change (IPCC) in 2007. Their review results show that while climate change can intensify conflicts, factors such as the presence of strong institutions can provide opportunities for peacebuilding and cooperation between communities affected by climate change impacts. The significance of promoting cooperation has also been highlighted by Fisher et al. (2021). They show that countries with cooperation-enabling institutions have a better performance in terms of achieving integrated sustainability indicators. However, as Sharifi et al. (2020) argue there has been more emphasis on the negative impacts (e.g., climateinduced civil and interstate conflicts) and security risks in the literature and further attention to positive impacts and interactions between peace and sustainability is needed. As an example of the positive impacts, Nicoson (2021) argue that transforming societal power structures and reducing inequalities are essential for facilitating climate-resilient peace and addressing social and environmental sustainability challenges. Similarly, based on his content analysis of four core reports of the United Nations Environment Programme (UNEP)'s Environmental Cooperation for Peacebuilding Programme (2008-2015), Krampe (2021) emphasizes the significance of reducing power inequalities for building and sustaining peace.

As a manifestation of global environmental change, increase in the frequency and intensity of (especially hydrometeorological) disasters has received a lot of attention in the literature of sustainability and climate change. The need for adaptation to disasters and adverse events is also highly emphasized in the Sendai Framework for Disaster Risk Reduction 2015-2030 (Sendai Framework). As Peters and Peters (2021), Ahmed et al. (2021), and Schismenos et al. (2021) discuss, disasters may also have major implications for peace and sustainability. Based on the analysis of data collected from ethnographic field visits to Rohingya refugee camps in Bangladesh, Ahmed et al. (2021) demonstrate that the compounding effects of conflicts, resource scarcities, and climate-induced disasters, such as extreme rainfalls, landslides, and flashfloods, can compromise efforts aimed at promoting peace and sustainability. They suggest that developing approaches for better engagement of refugees in the management and decision-making processes may help overcome some of the potential challenges. Such approaches could, for instance, be based on the humanitarian engineering paradigm that provides capacity-building opportunities and is based on participatory disaster risk reduction programs that are also aligned with climate-resilient and sustainable development pathways (Schismenos et al. 2021). Peters and Peters (2021) argue that while there is a lot of research showing how climate-induced disasters can undermine peace and amplify violent conflicts, the possibility of contributing to peacebuilding and sustainable development through well-managed and effective disaster risk reduction activities is relatively underexplored. They, therefore, argue that the tripartite connection between disaster risk reduction, sustainable development, and peacebuilding should be further studied, and the effective delivery of the Sendai Framework is critical for achieving sustainability as well as peace.

Some key insights to better address issues at the nexus of peace and sustainability can be obtained from these studies. First, while peace and sustainability can interact in multiple ways, the negative impacts of unsustainable actions on peacebuilding activities have received more attention. It is, therefore, essential to also pay attention to other pathways (i.e., how sustainability can contribute to peace, how peace can contribute to sustainability, and how lack of peace can undermine sustainability). Second, it is evident that systemic approaches are needed to capture the multiple dynamic 
interactions between peace and sustainability across different spatio-temporal scales. Given that the dynamics of peace, sustainability, and their nexus are largely influenced by local characteristics and cultures, such approaches should also respect context-specific issues and not be based on one-size-fits-all paradigms. Third, addressing issues at the intersection of peace and sustainability requires interactions between a wide range of stakeholders within and across various local, regional, national, and global scales (Miyazaki 2021). As Miyazaki (2021) argues, in addition to national and global actors, stakeholders at the local level can also take important roles. Fourth, as Kasuga (2021) suggests, international scientific collaboration is essential for a comprehensive understanding of the interactions between peace and sustainability. In this regard, global research networks can play an important role by creating a platform not only for interactions between researchers but also for engagement with a wide range of other stakeholders. This is likely to lead to more innovative solutions towards addressing peace and sustainability challenges in the context of global change.

We hope that this special feature will contribute to a better understanding of the complexities of the peace-sustainability nexus and provide insights into developing more effective solutions and strategies for making progress towards creating more peaceful and sustainable communities in the future. We acknowledge that further research is needed to better understand the complexities of the nexus. Therefore, we hope that this special feature will also stimulate further research and conversations on the peace-sustainability nexus in the coming years. The Network for Education and Research on Peace and Sustainability Conference from March 1-3, 2022 at Hiroshima University is one of the platforms for continuing this initiative and sustaining collaborative and transdisciplinary research. The Network for Education and Research on Peace and Sustainability, to which most contributing authors of this special feature belong, remains committed to producing knowledge on the nexus between peace and sustainability in collaboration with various stakeholders.

\section{References}

Ahmed S, Simmons WP, Chowdhury R, Huq S (2021) The sustainability-peace nexus in crisis contexts: how the Rohingya escaped the ethnic violence in Myanmar, but are trapped into environmental challenges in Bangladesh. Sustain Sci. https://doi.org/10.1007/ s11625-021-00955-6

Amadei B (2021) A systems approach to the sustainability-peace nexus. Sustain Sci. https://doi.org/10.1007/s11625-020-00902-x

Brock L (1991) Peace through parks: the environment on the peace research agenda. J Peace Res 28:407-423
Buhaug H, Gleditsch NP, Theisen OM (2008) Implications of climate change for armed conflict, social dimensions of climate change workshop. World Bank, Washington

Conca K, Dabelko GD (2002) Environmental peacemaking. Woodrow Wilson Center Press, Washington

Davenport C, Melander E, Regan PM (2018) The peace continuum: what it is and how to study it. Oxford University Press, New York

Fisher J, Arora P, Chen S, Rhee S, Blaine T, Simangan D (2021) Four propositions on integrated sustainability: toward a theoretical framework to understand the environment, peace, and sustainability nexus. Sustain Sci. https://doi.org/10.1007/ s11625-021-00925-y

Galtung J (1969) Violence, peace, and peace research. J Peace Res 6:167-191. https://doi.org/10.1177/002234336900600301

Hauge W, Ellingsen T (1998) Beyond environmental scarcity: causal pathways to conflict. J Peace Res 35:299-317. https://doi.org/10. $1177 / 0022343398035003003$

Hendrix CS, Haggard S (2015) Global food prices, regime type, and urban unrest in the developing world. J Peace Res 52:143-157. https://doi.org/10.1177/0022343314561599

Ide T (2020) The dark side of environmental peacebuilding. World Dev 127:104777. https://doi.org/10.1016/j.worlddev.2019.104777

IEP (2019) Global Peace Index 2019: measuring peace in a complex world. Institute for Economics and Peace, Sydney

IPCC (2014) AR5 Climate change 2014: impacts, adaptation, and vulnerability-IPCC. https://www.ipcc.ch/report/ar5/wg2/. Accessed 5 July 2014

Jarstad A, Eklund N, Johansson P, Olivius E, Saati A, Sahovic D, Söderström J, Wimelius ME, Åkebo M (2019) Three approaches to peace A framework for describing and exploring varieties of peace (No. 12), Umeå Working Papers in Peace and Conflict Studies. Umeå University, Umeå

Kasuga F (2021) Science as a common language for contribution to sustainability and peace. Sustain Sci. https://doi.org/10.1007/ s11625-021-00972-5

Koubi V (2019) Climate change and conflict. Annu Rev Polit Sci 22:343-360. https://doi.org/10.1146/annurev-polis ci-050317-070830

Koubi V, Bernauer T, Kalbhenn A, Spilker G (2012) Climate variability, economic growth, and civil conflict. J Peace Res 49:113-127. https://doi.org/10.1177/0022343311427173

Krampe F (2021) Ownership and inequalities: exploring UNEP's environmental cooperation for peacebuilding program. Sustain Sci. https://doi.org/10.1007/s11625-021-00926-x

Mac Ginty R, Firchow P (2016) Top-down and bottom-up narratives of peace and conflict. Politics 36:308-323. https://doi.org/10.1177/ 0263395715622967

Miyazaki H (2021) Hiroshima and Nagasaki as a model of city diplomacy. Sustain Sci. https://doi.org/10.1007/s11625-021-00968-1

Nicoson C (2021) Towards climate resilient peace: an intersectional and degrowth approach. Sustain Sci. https://doi.org/10.1007/ s11625-021-00906-1

Peters K, Peters LER (2021) Terra incognita: the contribution of disaster risk reduction in unpacking the sustainability-peace nexus. Sustain Sci. https://doi.org/10.1007/s11625-021-00944-9

Richmond O (2008) Peace in International Relations. Routledge, Oxon and New York

Schismenos S, Stevens GJ, Emmanouloudis D, Georgeou N, Shrestha S, Chalaris M (2021) Humanitarian engineering at the sustainability-development nexus: mapping vulnerability and capability factors for communities at risk of water-based disasters. Sustain Sci. https://doi.org/10.1007/s11625-020-00890-y

Sharifi A, Simangan D, Kaneko S (2020) Three decades of research on climate change and peace: a bibliometrics analysis. Sustain Sci. https://doi.org/10.1007/s11625-020-00853-3 
Sharifi A, Simangan D, Kaneko S (2021) The literature landscape on peace-sustainability nexus: a scientometric analysis. Ambio 50(3):661-678. https://doi.org/10.1007/s13280-020-01388-8

Simangan D, Virji H, Hendrix C, Islam M, Kaneko S, Ma YS, Mechler R, Pangotra P, Peters K, Sharifi A, Shams SH (2021) A codesigned heuristic guide for investigating the peace-sustainability nexus in the context of global change. Sustain Sci. https://doi.org/ 10.1007/s11625-021-00970-7

UN (2015) Transforming our world: the 2030 Agenda for Sustainable Development (No. UN Doc. A/RES/70/1). United Nations

UN WCED (1987) Our Common Future-Brundtland Report (No. UN Doc. A/42/427). United Nations World Commission on Environment and Development
Virji H, Sharifi A, Kaneko S, Simangan D (2019) The sustainabilitypeace nexus in the context of global change. Sustain Sci 14:14671468. https://doi.org/10.1007/s11625-019-00737-1

von Uexkull N, Croicu M, Fjelde H, Buhaug H (2016) Civil conflict sensitivity to growing-season drought. PNAS 113:12391-12396. https://doi.org/10.1073/pnas.1607542113

Publisher's Note Springer Nature remains neutral with regard to jurisdictional claims in published maps and institutional affiliations. 